JURNAL KETAHANAN NASIONAL

Vol. 24, No. 3, Desember 2018, Hal 287-305

DOI:http://dx.doi.org/ 10.22146/jkn.37734

ISSN:0853-9340(Print), ISSN:2527-9688(Online)

Online sejak 28 Desember 2015 di :http://jurnal.ugm.ac.id/JKN

VOLUME 24

No. 3, Desember 2018

Halaman 287- 305

\title{
Isu Perubahan Iklim Dalam Konteks Keamanan Dan Ketahanan Nasional
}

\author{
Adi Subiyanto \\ Prodi Klimatologi, Sekolah Pascasarjana, Institut Pertanian Bogor (IPB) \& Tentara Nasional \\ Indonesia Angkatan Udara (TNI AU) \\ Email:adisbyt@gmail.com
}

\section{Rizaldi Boer}

Centre for Climate Risk and Opportunity Management (CCROM),

Bogor Agricultural University

Email:rizaldiboer@gmail.com

\section{Edvin Aldrian}

IPCC Working Group I Vice Chair, Indonesia

Email:e_aldrian@yahoo.com

\section{Perdinan}

Departemen Geofisika dan Meteorologi, FMIPA, IPB

Email:perdinan@gmail.com

\section{Rilus Kinseng}

Departemen Komunikasi dan Pengembangan Masyarakat, FEMA, IPB

Email: rilus_kinseng@hotmail.com

\begin{abstract}
Climat change (CC) which contributed to increased conflict/war had implicitly emerged in the IPCC's 3rd and 4 th reports (IPCC, 2001; 2007); meanwhile on the 5th report (IPCC, 2014) emphasized more on human security. The risk/impact of CC to human security was shown through interaction between livelihood, conflict, culture, and migration. The purpose of the stydy was to gained an understanding of the correlation between CC and the occurrence of conflict/war; knowing the impacts of CC on national resilience; explaining the phenomenon of CC on national resilience; and explained the linkages between human security and national resilience.

This research was done through conceptual and comparative approach.

The results showed that $C C$ did not contribute directly to the occurrence of conflict/war; the impact of CC disrupts people's livelihoods thereby reducing national resilience; CC could be viewed as a disturbance and/or threat; and basically national resilience and human security could be synchronized because both of them seeked to brought guarantee for the security, safety, and individual prosperity.
\end{abstract}

Keywords: Climate Change, Conflict, Human Security, National Resilience 


\begin{abstract}
ABSTRAK
Perubahan iklim (PI) diasumsikan berkontribusi terhadap meningkatnya konflik/perang. Pandangan tersebut secara implisit telah muncul dalam laporan Panel Antarpemerintah tentang Perubahan Iklim(IPCC)ke-3 (IPCC TAR, 2001) dan ke-4 (IPCC AR4, 2007); sebaliknya pada laporan ke-5 (IPCC AR5, 2014) memfokuskan pada keamanan manusia. Skema risiko PI pada keamanan manusia ditunjukkan melalui interaksi antara mata pencaharian, konflik, budaya, dan migrasi. Penelitian ini untuk menjelaskan korelasi antara PI dengan terjadinya konflik/perang; menggambarkan dampak PI bagi ketahanan nasional (Tannas); menjelaskan isu PI ditinjau dari konsepTannas; dan menjelaskan keterkaitan antara keamanan manusia dengan Tannas. Penelitian dilakukan melalui dua pendekatan, yaitu: pendekatan konseptual dan pendekatan komparatif.

Diperoleh hasil bahwa PI tidak berkorelasi langsung terhadap terjadinya konflik/perang; PI mengganggu mata pencaharian masyarakat, sehingga menurunkan Tannas; dalam konsep Tannas, PI merupakan gangguan dan atau ancaman; dan Tannas dapat disetarakan dengan keamanan manusia karena keduanya berupaya menghadirkan penjaminan keamanan, keselamatan, dan kesejahteraan individu.
\end{abstract}

\title{
Kata Kunci: Perubahan Iklim, Konflik, Keamanan Manusia, Ketahanan Nasional.
}

\section{PENGANTAR}

Perubahan iklim (PI) dengan berbagai sebab dan dampaknya tidak hanya mempengaruhi proses pembangunan, tetapi juga terkait dengan sektor keamanan di semua negara. PI dapat meningkatkan konflik maupun perang (Barnet \&Adger, 2007). Konflik di negara-negara berkembang, diawali oleh persaingan mengakses sumberdaya alam (SDA) guna memperoleh penghidupan berkelanjutan (Olufemi \& Samson, 2012). Perebutan SDA akan menjadi model perang pada masa depan dan merubah tempat/titik konflik serta melahirkan kebijakan dan stategi perang yang baru (Klare, 2001). Apabila mengacu pada pernyataan Klare tersebut, maka kelimpahan SDA yang merupakan kekayaan alamiah Bangsa Indonesia justru dapat mengundang bencana/konflik. Kondisi yang demikian dapat diperumpamakan sebagai The Paradox of Plenty (Karl, 1997). SDA yang dimiliki bukan menjadi sumber kemakmuran tetapi justru menjadi sumber konflik karena diperebutkan oleh aktor internal negara, bahkan dapat mengundang aktor/kekuatan negara lain untuk menguasainya.

Pandangan tersebut juga tertuang dalam laporan Intergovermental Panel on Climate
Change (IPCC), yaitu laporan ke-3 atau TAR (IPCC, 2001) dan laporan ke-4 atau AR4 (IPCC, 2007). TAR danAR4 secara implisitmenyebutkan adanya korelasi antara PI dengan konflik/perang yang terjadi di dalam negara maupun antar negara. Sebaliknya pada laporan ke-5 atau AR5 (IPCC, 2014), PI tidak dikategorikan sebagai penyebab terjadinya konflik maupun perang, namun terkait dengan keamanan manusia (human security). Keamanan manusia terancam oleh PI melalui terganggunya mata pencaharian, peningkatan konflik, perubahan budaya, dan migrasi penduduk.

IPCC berperan dalam melakukan kajian ilmiah, memberikan informasi dan teknis yang dibutuhkan dalam menghadapi risiko/dampak potensial, serta pilihan tanggapan terhadap PI. IPCC membuat laporan kajian (assessment report atau AR) berdasarkan literatur ilmiah dari para expert(ahli) di bidang iklim. Dengan demikian, selain pandangan pada TAR, AR4, dan AR5 juga disertakan pandangan/pendapat dari para peneliti tentang korelasi antara PI dan terjadinya konflik/perang.

Konsep human security pertama kali muncul dalam Human Development Report Tahun 1994 (UNDP, 1994). Dalam laporan tersebut ditekankan bahwa human 
security bersifat universal dan sesuai bagi kehidupan sehari-hari. Ancaman dalam human security pada dasarnya bersifat umum dan tidak membedakan ke dalam batasan antar negara (transboundary). Human security menitikberatkan pada manusia, bukan pada negara. Human security mencakup tujuh wilayah keamanan,yaitu keamanan ekonomi, ketahanan pangan, keamanan kesehatan, keamanan lingkungan, keamanan individu, keamanan komunitas, dan keamanan politik.

Sejauh ini, meskipun telah memiliki undang-undang (UU) tentang Polri (UU No. 2/2002), Pertahanan Negara (UU No. 3/2002), dan TNI (UU No. 34/2004) namun belum ada UU tentang Keamanan Nasional. Di sisi lain, Indonesia memiliki konsep Ketahanan Nasional (Tannas) yang dapat disetarakan dengan keamanan manusia maupun keamanan komprehensifkarena sudah mencakup perlindungan bagi warganya. Konsep Tannas telah mencakup semua aspek kehidupan; termasuk ketangguhan dalam menghadapi berbagai bentuk tantangan, hambatan, gangguan, dan ancaman (THGA) yang membahayakan keberadaan bangsa sehingga Tannas sering diartikan sebagai konsep survival bangsa (Suradinata, 2005).

Penelitian ini membahas bagaimana keterkaitan antara kejadian konflik/perang dengan fenomena PI (terutama iklim ekstrim) dengan mempertimbangkan perubahan bentuk perang dan trend global 2030; dampak apa yang ditimbulkan oleh PI bagi Tannas; membandingkan kebijakan keamanan di beberapa negara, bagaimana seharusnya menempatkan PI dalam perspektif Tannas; dan bagaimana keterkaitan antara keamanan manusia dengan Tannas.

Berdasarkan permasalahan tersebut maka tujuan dari penelitian adalah (1).
Memperoleh pemahaman tentang korelasi antara PI dengan terjadinya konflik/perang; (2). Menggambarkan dampak PI bagi Tannas; (3). Menjelaskan isu PI dalam perspektif Tannas dengan cara mengklasifikasikannya dalam tantangan, hambatan, gangguan atau ancaman; dan (4). Menjelaskan keterkaitan antara keamanan manusia dengan Tannas.

Penelitian dilakukan dengan dua pendekatan, yaitu pendekatan konseptual dan pendekatan komparatif. Pendekatan konseptual dilakukan berdasarkan konsep dari para ahli terkait dengan pokok pembahasan (Soemitro, 1988). Pendekatan ini digunakan terhadap konsep-konsep, hukum maupun doktrindoktrin yang melatarbelakanginya (Soekanto dan Mamuji, 2001). Pendekatan konseptual yang dimaksudkan yaitu pandangan IPCC tentang korelasi antara PIdengan terjadinya konflik/perang dan keamanan manusia; serta undang-undang tentang sistem pertahanankeamanan rakyat semesta dalam UUD' 45. Selain itu, mengacu pada konsepsi tentang keamanan nasional, Tannas, keamanan komprehensif, dan keamanan manusia.

Pendekatan komparatif merupakan metode yang melakukan perbandingan antaradua obyek atau lebih untuk menambah pemahaman tentang obyek yang telah diketahui sebelumnya namun belum tegas serta jelas. Tanpa perbandingan maka semua pemikiran ilmiah tidak dapat dibayangkan (without comparation all scientific thought is unimaginable) (Klingman, 1980). Beberapa kondisi/kejadian yang diperbandingkan, yaitu kejadian El-Nino dengan terjadinya konflik/perang, tren kejadian bencana (hidrometeorologi) 10 tahun terakhir, jumlah kematian akibat konflik/perang, kebijakan keamanan di empat negara (AS, Australia, Inggris dan Indonesia). Setidaknya, ada 2 
Gambar 1

Tahun Terjadinya El-Nino Dan La-Nina Berdasarkan Indeks ONI

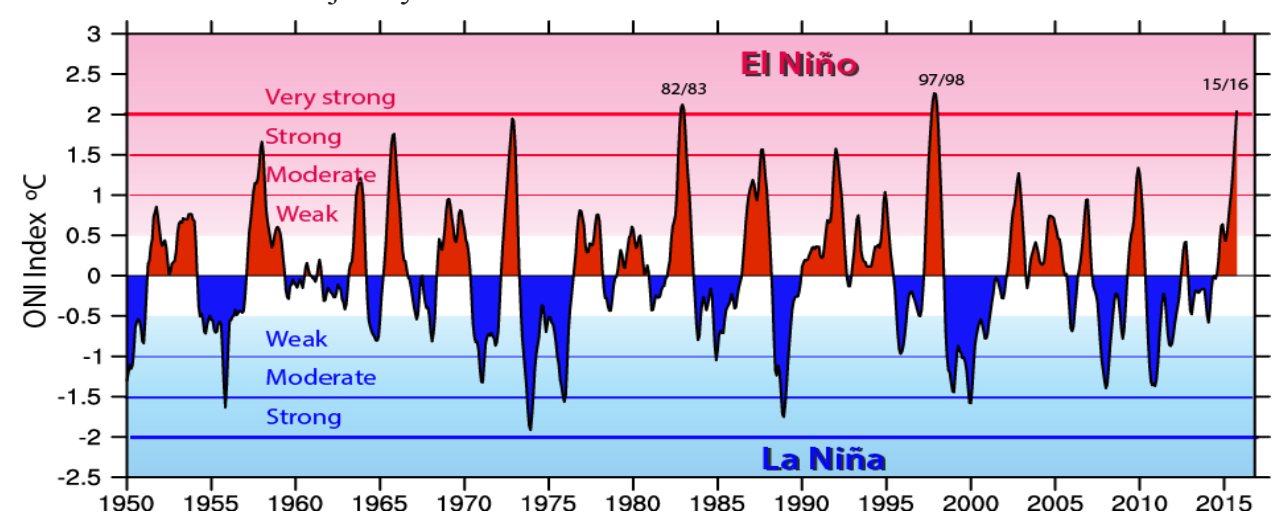

(Sumber: Trenberth \& NCAR, 2016)

(dua) alasan mengapa perlu membandingkan pandangan dan policy (kebijakan), yaitu dapat mempertajam klasifikasi dalam membuat prediksi (Hague \& Harrop, 2013).

\section{PEMBAHASAN}

\section{PI dan Potensi Terjadinya Konflik/Perang}

Laporan Kajian IPCC yang ke-5 menyatakan bahwa PI akan tetap berlangsung bahkan meningkat sehingga berdampak terhadap kondisi sosialekonomidan lingkungan (IPCC, 2014). Negara berkembang sangat terdampak karena faktor keterpaparan secara geografis, ketergantungan pada sektor yang sensitif terhadap iklim, pendapatan rendah, dan kapasitasnya dalam melakukan adaptasi yang rendah (Stern, 2008). Kondisi tersebut menyebabkan negara berkembang sangat rentan dari berbagai dampak PI dan cuaca ekstrim.

Para pemerhati di bidang iklim, sebagian besar memandang bahwa PI merupakan penyebab migrasi penduduk dan terjadinya konflik. Kemiskinan dan ketergantungan pada sektor pertanian yang diperparah oleh badai, banjir, dan kekeringan menyebabkan 12-17 juta penduduk Banglades (Pakistan Timur sebelum 1971) pindah ke India sejak tahun 1950-an (Swain, 1996). Kedatangan imigran Banglades di India menyebabkan kekerasan/ konflik pada 1980-an (Homer-Dixon, 1999). Contoh lain, kedatangan imigran karena degradasi lingkungan dari El Salvador di Honduras akhirnya menyebabkan perang pada 1969 antara kedua negara (Durham, 1979).

PI dikategorikan sebagai threat multiplier atau ancaman pengganda (CNA-MAB, 2007) yang akan menyebabkan meningkatnya peristiwa kekeringan, kelaparan, dan migrasi sehingga dapat memicu lebih banyak konflik selama beberapa dekade. PI dipandang sebagai akar penyebab terjadinya migrasi dan pengungsi Suriah yang tiba di Eropa dikategorikan sebagai imigran iklim (climate migrants) dan pengungsi iklim (climate refugees) (Baker, 2015; Dinshaw, 2015). Kemungkinan adanya keterkaitan antara PI dengan terjadinya konflik telah disebutkan secara implisit pada laporan IPCC ke-3 (TAR) dan ke-4 (AR4).

Terdapat beberapa indeks yang digunakan untuk memantau tropical pacific, kesemuanya didasarkan pada terjadinya anomali suhu yang tercatat selama 30 tahun atau lebih. Indeks NINO3 dan ONI (oceanic nino index) adalah indeks yang umum 
Gambar 2

Indeks NINO3 Dan Probabilitas Konflik

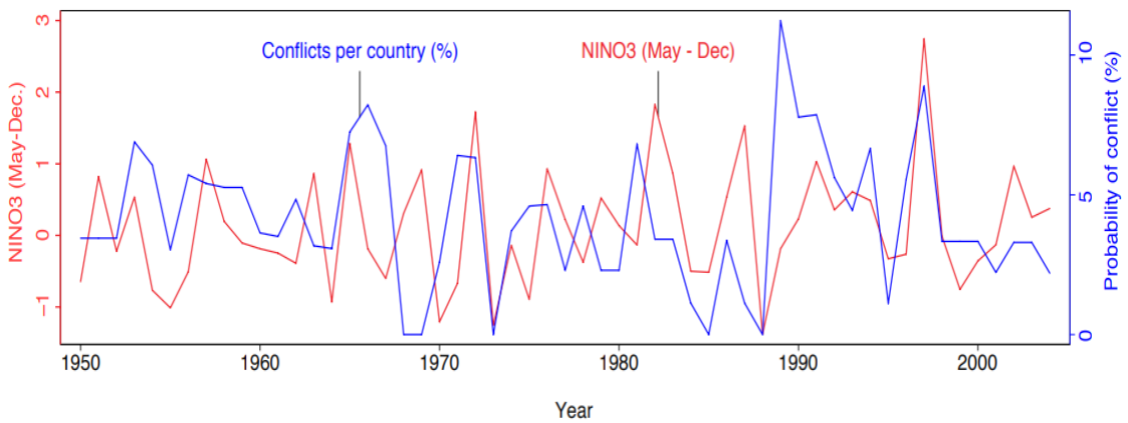

(Sumber: Hsiang \& Cane, 2011)

digunakan dalam menentukan terjadinya El-Nino dan La-Nina (Trenberth \& NCAR, 2016). Mencermati kejadian El-Nino tahun 1997/1998 (gambar1), pada tahun yang sama Indonesia juga mengalami krisis ekonomi (moneter) yang mendorong pergantian regim orde baru menuju orde reformasi.

Menyikapi hal tersebut, menjadi menarik untuk mengetahui apakah PI berpengaruh terhadap terjadinya konflik/perang? PI umumnya mempengaruhi keamanan secara tidak langsung. PI dapat memperparah tingkat kemiskinan, ketidakstabilan politik, dan populasi yang telah padat (Fearon \& Laitin, 2003). Kemiskinan dan ketidakstabilan politik inilah yang dapat memicu terjadinya konflik inter state maupun intra state. Pengaruh potensial terhadap terjadinya konflik/perang juga disebabkan oleh kerentanan infrastruktur air dan energi, ketergantungan pada rantai pasokan komoditas, kelembagaan sosial dan politik, dan kemampuan beradaptasi dari komunitas/masyarakat (Dellmuth dkk, 2017).

Hsiang \& Cane (2011) membuat model keterkaitan antara kejadian El-Nino dengan probabilitas konflik/perang (gambar 2). Namun, perubahan dan kejadian iklim ekstrim cukup lemah apabila dikategorikan sebagai pemicu konflik bersenjata. Bukti menunjukkan konflik/perang sipil di Afrika diakibatkan oleh penguasaan politik pada etnis tertentu dan ekonomi nasional yang buruk (Buhaug, 2010). Pendapat serupa disampaikan oleh Miguel dkk (2004), peningkatan konflik di Afrika lebih disebabkan oleh kemerosotan pertumbuhan ekonomi. NINO3 diprediksi mengalami peningkatan suhu sebesar $2^{\circ} \mathrm{C}$ pada 2100 dan berkorelasi terhadap peningkatan terjadinya konflik per tahun sebesar 4,1\% - 5,7\% (Hsiang \& Cane, 2011).

Peningkatan suhu dan peningkatan konflik tidak menunjukkan kausalitas, meskipun keduanya menunjukkan kecenderungan peningkatan yang sama. Jumlah konflik yang terjadi antara tahun 1946-2014 (gambar 3 ) menunjukkan tren yang sama dengan kejadian El-Nino. Tidak cukup alasan untuk menyimpulkan bahwa PI memiliki peran yang dominan sebagai penyebab terjadinya konflik bersenjata (Gleditsch, 2012). Namun, PI diproyeksikan semakin meningkatkan risiko yang telah ada dan menciptakan risiko baru bagi sistem alam dan manusia.

Berdasarkan laporan IPCC (2014), terdapat sebelas sektor yang terdampak oleh PI, yaitu sumber daya air tawar, ekosistem daratan dan air tawar, sistem pantai dan daerah dataran rendah, sistem kelautan, sistem 
Gambar 3

Jumlah Konflik/Perang 1946-2014

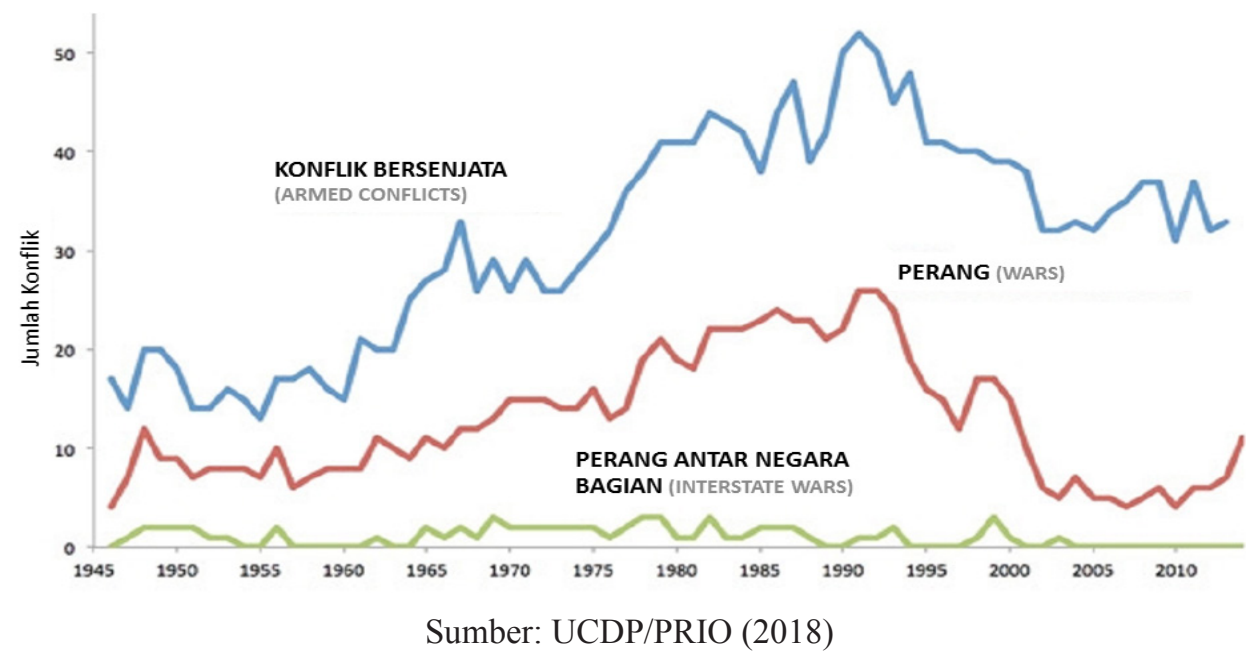

ketahanan pangan dan produksi pangan, daerah perkotaan, daerah pedesaan, sektor utama ekonomi dan pelayanan, kesehatan manusia, keamanan manusia, serta mata pencaharian dan kemiskinan.

JikaPI tidak berpengaruh langsung terhadap terjadinya konflik/perang, apakah degradasi lingkungan berkontribusi terhadap konflik? Bernauer \& Koubi (2012) menyimpulkan bahwa tidak ada korelasi langsung antara degradasi lingkungan dengan konflik. Banyaknya kejadian bencana dari iklim ekstrim juga tidak mendorong terjadinya konflik bersenjata (Bergholt \&Lujala, 2012). Sebaliknya, tidak cukup bukti untuk mengatakan variabilitas iklim berpengaruh terhadap memburuknya perekonomian. Namun beberapa kerusuhan/konflik di negara non demokratis, konflik terjadi manakala kondisi ekonomi memburuk (Koubi dkk, 2012).

Demikian juga dengan dua negara yang berbagi sungai (sungai yang melewati 2 negara), tidak memicu terjadinya konflik. Risiko terjadinya konflik, jika pada salah satu diantara negara berdekatan memiliki wilayah yang merupakan hulu atau hilir dari sungai yang digunakan bersama (Brochmann
\&Gleditsch, 2012). Banglades adalah negara yang memiliki 54 sungai dan dimanfaatkan untuk sektor pertanian namun alirannya berasal dari Sungai Gangga di India (Khalid, 2010). Semenjak dibangunnya Dam Farakka di India menyebabkan sungai-sungai di Bangladesh yang berhulu sungai di India menjadi kekurangan air untuk pertanian. Kondisi tersebut dapat memicu terjadinya konflik antar kedua negara, padahal masa sebelum pembangunan Dam Farakka situasinya jauh lebih baik (Kawser \& Samad, 2016).

Dalam era PI, interaksi antara ketersediaan air dan ketidakamananpangan, termasuk salah urus SDA merupakan kondisi yang berkontribusi terhadap ketidakamanan dan terjadinya peristiwa kekacauan/konflik di Suriah (Werrel dkk, 2015). Namun, jika menganggap faktor eksternal (seperti kekeringan)meningkatkan terjadinya pemberontakan/konflik di Suriah adalah kontraproduktif. Hanya akan mengalihkan permasalahan mendasar yaitu ketidakstabilan politik maupun kemerosotan ekonomi dan seolah-olah kerusuhan yang terjadi bukan 
Gambar 4

Tingkat Kematian Akibat Pertempuran Berdasar Jenis Konflik Sejak 1946

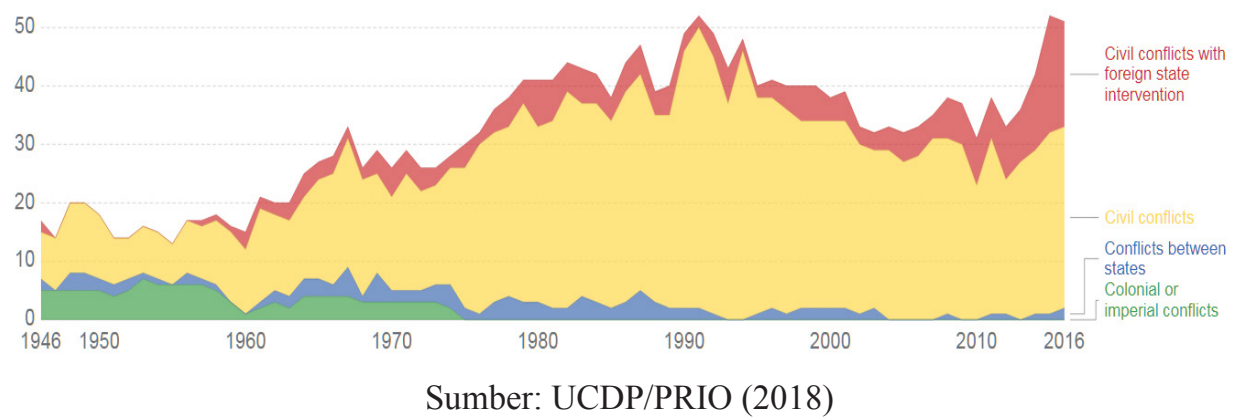

merupakan tanggung jawab dari negara/ pemerintah (De Chatel, 2014).

\section{Perubahan Bentuk Perang dan Trend Global 2030}

Sejak tahun 1946 jumlah kematian pada perang sipil lebih banyak dibandingkan dengan perang antar negara maupun perang yang dipicu oleh intervensi negara lain (gambar 4). Penyebab terjadinya perang sipil/konflik internal di antaranya adalah kemiskinan, kekurangan pangan, dan ketimpangan pendapatan. Semenjak 1992, jumlah konflik bersenjata turun $40 \%$ dan peperangan tidak mengakibatkan banyak korban meninggal. Jumlah kematian di daerah konflik/perang, 90\% disebabkan oleh penyakit dan kekurangan stock pangan (HSC, 2005).

Tren perubahan global yang diprediksi terjadi di 2030 (NIC, 2012), akan terjadi perubahan dengan empat skenario potensial (tabel 1). Skenario yang paling mengkhawatirkan adalah adanya peningkatan kebutuhan terhadap SDA, yaitu akses ke

Tabel 1

Tren Global 2030 (Sebuah Gambaran)

\section{MEGATRENDS (Kecenderungan Besar)}

Pemberdayaan Individu

Difusi Kekuatan

Pola Demografi

Kebutuhan

Makanan, Air, dan Energi
Pemberdayaan individu akan mempercepat pengurangan kemiskinan, peningkatan kelas menengah, pencapaian pendidikan yang lebih besar, penggunaan teknologi komunikasi dan manufaktur baru secara luas, dan kemajuan perawatan kesehatan.

Tidak ada kekuatan yang hegemoni dan berubah dalam koalisi yang multipolar.

Ketidakstabilan pola demografisakan menyempit. Perekonomian merosot di negara yang didominasi oleh penduduk usia tua. Penduduk $60 \%$ tinggal di kota dan migrasi akan meningkat.

Permintaan kebutuhan ini akan tumbuh secara substansial karena jumlah penduduk meningkat. Mengatasi masalah satu satu komoditas akan terkait dengan komoditas lain.

\section{POTENTIAL WORLDS (Kemungkinanan Dunia yang Baru)}

\begin{tabular}{ll}
\hline Penggerak Terhenti & $\begin{array}{l}\text { Dalam skenario terburuk, risiko terjadinya konflik antarnegara meningkat. AS menarik } \\
\text { kekuatan ke dalam dan globalisasi berhenti. }\end{array}$ \\
Perpaduan & $\begin{array}{l}\text { Cina dan AS berkolaborasi dalam berbagai masalah dan melakukan hubungan yang lebih } \\
\text { kompleks. }\end{array}$ \\
Yang tidak mungkin & $\begin{array}{l}\text { Ketimpangan meledak karena beberapa negara menjadi pemenang besar dan yang lainnya } \\
\text { dihentikan }\end{array}$ \\
gagal. Ketimpangan meningkatkan konflik internal dan AS bukan lagi "polisi dunia." \\
Aktor non negara & Aktor non-negara memimpin dalam merespon tantangan global. \\
\hline
\end{tabular}


makanan, energi, dan kebutuhan akan air menjadi semakin krusial. Prediksi tersebut menunjukkan jika dampak PI semakin mengkhawatirkan.

Para peneliti di Laboratorium Nasional Sandia (Sandia National Laboratories) mengembangkan Indeks Ketahanan Manusia atau Human Resilience Index (HRI) (NIC, 2012) dalam mengembangkan hubungan antara kondisi ekologi-manusia, ketahanan manusia, dan konflik. Tujuh indikator untuk menghitung HRI, yaitu tingkat pertumbuhan penduduk, kepadatan penduduk, kebutuhan kalori per kapita, air tawar terbarukan per kapita, lahan subur per kapita, usia pertengahan (median), dan kondisi kesehatan (termasuk kematian bayi/anak dan harapan hidup). Tabel 2 mencantumkan negara-negara yang diproyeksikan sebagai negara gagal pada 2030 yang diawali oleh ketidakstabilan, konflik, atau beberapa jenis kegagalan negara lainnya karena kondisi ekologi dan ketahanan manusia yang buruk. Dari tabel 2 tersebut, yang paling rawan menjadi negara gagal pada 2030 adalah Somalia, diikuti oleh Burundi dan Rwanda.

Tren global pada 2030 ini tidak terkait dengan novel The Next World War: Ghost Fleet. Indonesia dikisahkan sudah tidak memiliki kedaulatan sebagai sebuah negara. Indonesia disebutkan sebagai bekas negara Indonesia. Dalam novel tersebut, China memandang
Indonesia sebagai bekas negara yang penting karena memiliki cadangan energi. Berdasar prediksi NIC (2012), Indonesia tidak termasuk 15 negara gagal (fail state) pada 2030.

\section{Dampak PI terhadap Tannas}

PI terjadi secara global namun dampak yang ditimbulkannya bervariasi secara lokal. Indikasi terjadinya PI di Indonesia dapat dilihat dari adanya peningkatan cuaca ekstrim (banjir dan kekeringan), peningkatan suhu udara, maju mundurnya musim, dan perubahan jumlah volume hujan (Aldrian dkk, 2011). Salah satu penyebab meningkatnya kejadian banjir dapat dilihat dari pengamatan di Stasiun Meteorologi Hasanudin (Makassar), dimana intensitas hujan $20 \mathrm{~mm} /$ hari meningkat sebesar $0,05 \%$ per tahun. Indikasi lainnya adalah secara umum suhu di Indonesia baik suhu minimum, rata-rata, dan maksimum memiliki tren yang meningkat sebesar $0.03{ }^{\circ} \mathrm{C}$ per tahun (BMKG, 2018).

Menurut Aldrian dkk (2011), indikasi dan dampak PI di Indonesia juga telah dirasakan baik secara langsung (fisik) maupun secara tidak langsung (nonfisik). Secara fisik, indikasi dan dampak PI telah dirasakan oleh berbagai lapisan masyarakat yang meliputi: (1). Peningkatan intensitas curah hujan menyebabkan perubahan ketahanan dari berbagai komoditas pertanian khas tropis; (2). Anomali iklim dan musim menyebabkan

Tabel 2

Prediksi 15 Negara Gagal di 2030

\begin{tabular}{rlrl}
\hline \multicolumn{4}{c}{$\begin{array}{c}\text { Negara-negara yang Diprediksi sebagai Negara Gagal pada 2030 } \\
\text { Ranking } \mathbf{1} \mathbf{- 1 5}\end{array}$} \\
\hline No Negara & No Negara & No Negara \\
\hline 1 Somalia & 6 Afganistan & 11 Niger \\
2 & Burundi & 7 Malawi & 12 Pakistan \\
3 & Rwanda & 8 Kongo & 13 Chad \\
4 & Yaman & 9 Nigeria & 14 Haiti \\
5 & Uganda & 10 Nigeria & 15 Etiopia \\
\hline
\end{tabular}

Sumber: Sandia National Laboratories (dalam NIC, 2012 hal.19) 


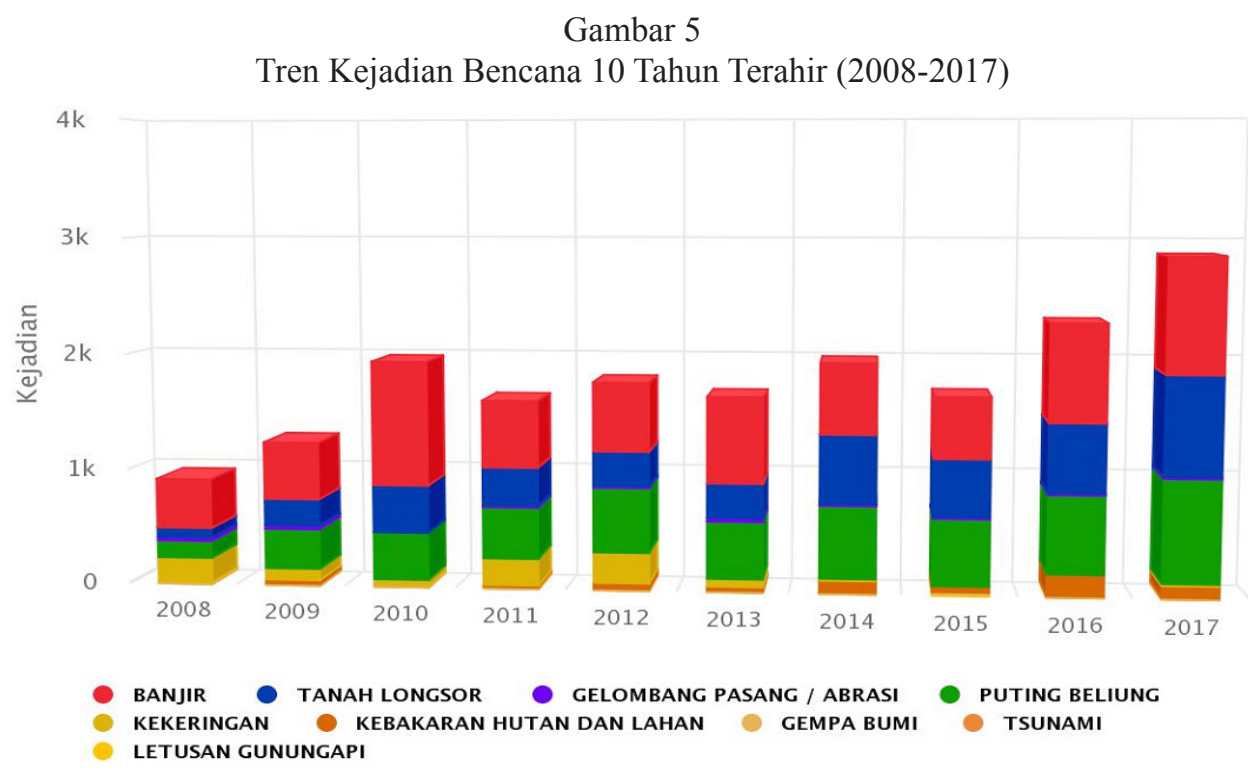

Sumber: BNPB (2018)

berbagai macam dampak, yaitu penurunan produksi pertanian/perkebunan/perikanan, gangguan transportasi maupun gangguan pada beberapa spesies hewan dan tumbuhan; (3). Meningkatnya kekeringan memicu kasus kebakaran hutan di beberapa wilayah di Indonesia; (4). Peningkatan temperatur permukaan menimbulkan perbedaan tekanan udara antar tempat sehingga memicu kenaikan frekuensi kejadian angin puting beliung; (5). Kejadian iklim ekstrim, di saat ElNino maka kekeringan mengancam areal pertanian; sebaliknya di saat La Nina sering mengakibatkan banjir; dan (6). Terjadinya rob yaitu muka laut meluber ke daratan akibat gelombang pasang.

Masih menurut Aldrian dkk (2011), dampak PI secara non fisik terjadi akibat hubungan tidak langsung yang pada akhirnya mengganggu aktivitas kehidupan manusia. Beberapa sektor yang sensitif terhadap dampak PI adalah (1). Kesehatan, kasus demam berdarah (DBD) dan malaria meningkat yang disebabkan oleh naiknya suhu udara pada masa transisi antar musim; (2). Infrastruktur, kerusakan infrastruktur sebagai akibat dari peningkatan curah hujan yang ekstrim; (3). Energi, penurunan intensitas curah hujan pada musim kemarau menyebabkan pasokan air untuk pembangkit listrik tenaga air (PLTA) berkurang; (4).Pertanian, pergeseran musim hujan/kemarau mempengaruhi pola tanam dan perubahan suhu menyebabkan peningkatan hama penyakit; (5). Kelautan dan perikanan, perubahan suhu muka laut dapat menyebabkan perubahan lokasi tangkapan ikan; (6). Wisata, terjadinya banjir rob di wilayah pesisir dapat merusak infrastruktur wisata; dan (7). Transportasi, peningkatan curah hujan ekstrim dan perubahan pola angin dapat menyebabkan terganggunya transportasi baik di darat, laut, maupun udara.

PI juga turut berkontribusi terhadap peningkatan kejadian bencana hidrometeorologi. Bencana hidrometeorologi yang meliputi banjir, kekeringan, tanah longsor, puting beliung, hingga gelombang pasang bahkan telah menjadi ancaman terbesar negara di Asia, termasuk Indonesia. Dengan frekuensi kejadian yang banyak, kelompok 
bencana ini juga memberikan dampak yang sangat besar terutama pada sektor ekonomi dan lingkungan, baik dampak langsung maupun dampak tidak langsung.

Selama kurun waktu 2008-2017, bencana hidrometeorologi merupakan bencana terbesar dan menunjukkan tren peningkatan (gambar 5). Sebagai contoh, sepanjang tahun 2017 terjadi 2.862 kejadian bencana (BNPB, 2018).Dari 2.862 tersebut, sebanyak 2.820 merupakan bencana hidrometeorologi yang terdiri dari banjir (979), puting beliung (886), tanah longsor (848), kebakaran hutan dan lahan (96), dan kekeringan (19). Dengan kata lain, bencana yang terjadi di Indonesia sebanyak 98,5 \% merupakan bencana hidrometeorologi.

Apabila mengacu pada UUD'45 maka negara berkewajiban untuk memastikan setiap penduduk memiliki tingkat kehidupan yang sejahtera dan memperoleh tempat tinggal yang layak. Di sisi lain, PI dan bencana hidrometeorologi memberikan dampak yang sangat besar terhadap Tannas, terutama pada gatraekonomi, sosialbudaya, dan lingkungan (geografi).Lebih spesifik lagi, PI berdampak terhadap Tannas melalui terganggunya kehidupan sosialekonomi masyarakat, terutama dari sisi mata pencaharian (livelihood). Masyarakat yang menggantungkan hidup dari bertani/berladang dan sebagai nelayan sangat terpengaruh oleh PI.

\section{Perubahan Iklim dan Kebijakan Keamanan}

Pada Maret 2008, Majelis Tinggi Uni Eropa yang membidangi masalah kebijakan luar negeri dan keamanan mengusung kesepakatan PI sebagai a threat multiplier which extrabates existing trends, tensions, and instability. PI dapat dikategorikan sebagai ancaman pengganda (threat multiplier) yang akan memperparah sehingga meningkatkan ketidakstabilan bagi negara-negara yang fragile dan tengah dilanda konflik (Dabelko, 2008). Beberapa alasan terjadinya konflik yang diperparah oleh PI, adalah meningkatnya kompetisi terhadap sumberdaya alam, terjadinya perpindahan penduduk, dan adanya tekanan tambahan pada sistem sosial-ekonomi dan lingkungan (USAID, 2009).

Ancaman PI menjadi perhatian oleh banyak negara di dalam menyusun kebijakan keamanan, salah satunya dituangkan dalam Defence White Paper (DWP). Pada tahun 2010, Departemen Pertahanan AS telah merumuskan PI sebagai ancaman keamanan nasional dan dituangkan dalam Quadrenial Defence Review2010(QDR, 2010), dilanjutkan dengan QDR 2014. Australia dalam DWP 2016 bahkan menyebutkan ancaman PI sebagai Threat Multiplier melalui skenario kegagalan sebuah negara atau failed state(DWP, 2016). QDR merupakan kebijakan pertahanan AS yang disusun setiap empat tahun dan di Indonesia dikenal sebagai Buku Putih Pertahanan (BPPI, 2015).

Isu PI dikategorikan sebagai ancaman sehingga dimasukkan dalam Defence White Paper (DWP)di beberapa negara; seperti Amerika, Australia, dan Inggris. Kebijakan tersebut menunjukkan bahwa PI telah disadari sebagai bentuk ancaman yang mengancam pertahanan/keamanan negara. Kaitannya dengan dimensi ancaman yang telah berubah maka dalam penyusunan kebijakan keamanan perlu mempertimbangkan berbagai sumber ancaman, tidak terkecuali ancaman PI.

\section{PI Dalam Perspektif Keamanan Manusia dan Ketahanan Nasional}

Skema risiko PI terhadap keamanan manusia ditunjukkan melalui interaksi antara 


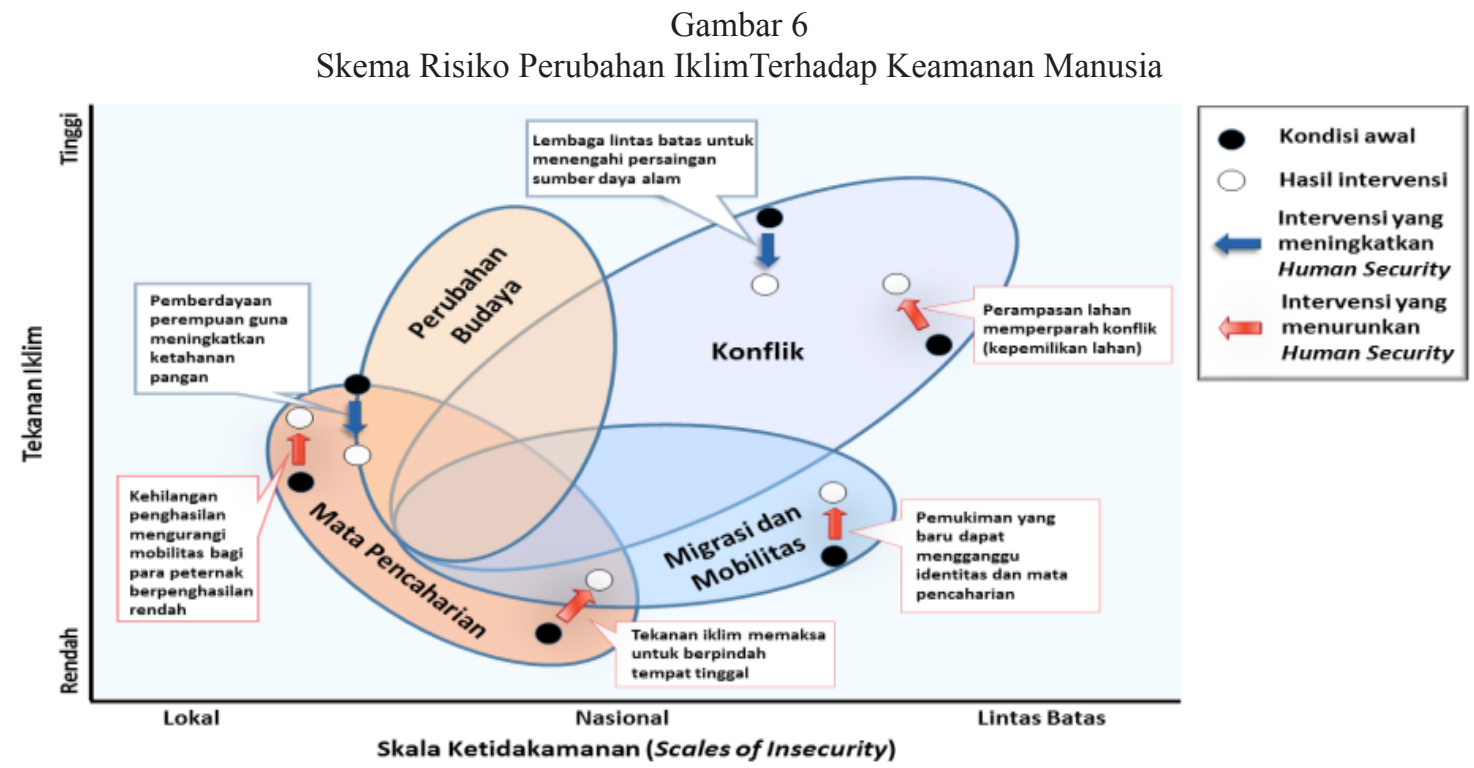

(Sumber: IPCC WGII AR5, 2014:hal. 39)

mata pencaharian, konflik, budaya, dan migrasi (IPCC, 2014). Intervensi dan kebijakan ditunjukkan oleh perbedaan antara kondisi awal (lingkaran hitam) dan hasil intervensi (lingkaran putih). Beberapa intervensi (panah biru) menunjukkan peningkatan dalam keamanan manusia, sebaliknya menunjukkan penurunan dalam keamanan manusia (panah merah) (gambar 6).

Ketidakamanan (insecurity) tidak memiliki penyebab tunggal tetapi merupakan interaksi dari berbagai faktor. PI merupakan faktor penting yang mengancam keamanan manusia, yaitu merongrong mata pencaharian, meningkatkan konflik, mengorbankan budaya dan identitas, dan meningkatkan migrasi yang sebetulnya lebih suka untuk menghindari. Kesemuanya itu menantang kemampuan negara untuk menyediakan kondisi bagi terwujudnya keamanan manusia.

Pandangan tentang dampak PI terhadap keamanan manusia merupakan salah satu pembahasan dalam AR5 (2014); sebuah pandangan yang cukup berbeda dibandingkan dengan TAR (2001) dan AR4 (2007) yang menyebutkan adanya keterkaitan antara PI dengan terjadinya konflik. AR5 menyebutkan salah satu dampak PI yang mengancam human security adalah migrasi akibat dari perubahan lingkungan. Namun, mengasumsikan bahwa penyebab terjadinya migrasi dikarenakan oleh perubahan lingkungan adalah kesalahpahaman. Keputusan melakukan migrasi sangatlah komplek, tidak hanya ditentukan oleh faktor lingkungan saja karena migrasi terkait juga dengan masalah keamanan (Frohlich, 2016). Lima alasan yang mendorong keputusan melakukan migrasi adalah ekonomi, politik, sosial, kependudukan, dan lingkungan (Black dkk, 2011).

Di sisi lain, konflik dan migrasi yang dilakukan oleh penduduk Suriah (Syria) bukan disebabkan oleh PI (Selby dkk, 2017). Demikian juga tentang adanya klaim bahwa dunia telah memasuki era baru ketidakamanan pasca perang dingin, dimana faktor kependudukan dan lingkungan mengancam keamanan dan stabilitas negara, nampaknya tidak mendasar; termasuk adanya tekanan kuat pada keamanan sehingga menjadi alasan untuk 
Gambar 7

Perubahan Iklim: Tantangan, Hambatan, Gangguan, atau Ancaman

\begin{tabular}{|c|c|c|c|}
\hline Bersumber dari Dalam & & Bersumber dari Luar & KRISIS \\
\hline TANTANGAN & HAMBATAN & GANGGUAN & ANCAMAN \\
\hline $\begin{array}{l}\text { Sesuatu masalah yang } \\
\text { bersifat atau bertujuan } \\
\text { menggugah kemampuan. } \\
\text { Konsekuensinya, apabila } \\
\text { berhasil mengatasi maka } \\
\text { negara menjadi semakin } \\
\text { kuat. Apabila gagal akan } \\
\text { menjadi negara yang kerdil. }\end{array}$ & $\begin{array}{l}\text { Sesuatu masalah yang } \\
\text { bersifat atau bertujuan } \\
\text { mengubah dan merombak } \\
\text { kebijaksanaan yang } \\
\text { dilandaskan secara } \\
\text { konsepsional (berasal dari } \\
\text { dalam). } \\
\text { Konsekuensinya, apabila } \\
\text { berhasil mengatasi maka } \\
\text { negara menjadi semakin } \\
\text { mempunyai ketahanan dan } \\
\text { semakin kuat. Apabila gagal } \\
\text { akan menjadi negara yang } \\
\text { lemah. }\end{array}$ & $\begin{array}{l}\text { Gangguan adalah } \\
\text { hambatan yang berasal } \\
\text { dari luar. } \\
\text { Konsekuensinya, apabila } \\
\text { berhasil mengatasi maka } \\
\text { negara menjadi semakin } \\
\text { mempunyai kepekaan } \\
\text { terhadap perubahan } \\
\text { sehingga semakin } \\
\text { mempunyai ketahanan dan } \\
\text { semakin kuat. Apabila gagal } \\
\text { akan menjadi negara yang } \\
\text { tidak kerdil, tidak lemah, } \\
\text { tetapi mudah jatuh atau } \\
\text { dikalahkan. }\end{array}$ & $\begin{array}{l}\text { Sesuatu masalah yang } \\
\text { bersifat atau bertujuan } \\
\text { mengubah dan merombak } \\
\text { kebijaksanaan yang } \\
\text { dilandaskan secara } \\
\text { konsepsional. } \\
\text { Konsekuensinya, apabila } \\
\text { berhasil mengatasi maka } \\
\text { negara menjadi semakin } \\
\text { mempunyai kepekaan yang } \\
\text { tinggi terhadap peristiwa, } \\
\text { termasuk perubahan yang } \\
\text { membahayakan negara. } \\
\text { Apabila gagal, negara } \\
\text { menjadi kolaps, dalam } \\
\text { jangka waktu tertentu atau } \\
\text { permanen. }\end{array}$ \\
\hline
\end{tabular}

(Dikembangkan oleh Peneliti)

mengurangi pertumbuhan penduduk global tampaknya tidak beralasan (Urdal, 2005)

Sebagai negara yang berdaulat, Indonesia memiliki konsepsi Tannas yang merupakan konsepsi geostrategi sebagai sebuah bangsa. Tannas dapat diformulasikan sebagai kemampuan warga negara dan bangsa untuk menghadapi tantangan, hambatan, gangguan, dan ancaman yang membahayakan kehidupan warga dan keberlangsungan bangsa. Konsep Tannas harus ditinjau dari kerangka fungsi ganda, yaitu melindungi aspek alamiah (geografi, penduduk, dan sumberdaya alam) dan aspek sosial (ideologi, politik, ekonomi, sosial-budaya, dan pertahanan/ keamanan atau sering disebutkan dengan Ipoleksosbudhankam. Tannas dapat dikatakan sebagai konsep survival agar mampu bertahan sebagai bangsa yang berdaulat (Suradinata, 2005).

PI dalam perspektif Tannas, apakah merupakan tantangan, hambatan, gangguan atau ancaman (THGA)?. Untuk menjawabnya, perlu adanya definisi tentang THGA dalam konsep Tannas (gambar 7). Penetapan PI termasuk kategori tantangan, hambatan, gangguan atau ancaman; masing-masing akan memiliki konsekuensi tersendiri. Berdasarkan gambar 7, PI dapat dikategorikan sebagai gangguan dan atau ancaman karena bersumber dari luar.

Selanjutnya, apabila mengacu pada analisis potensi dan kendala secara internal dan eksternal maka THGA dapat dikelompokkan sebagaimana pengelompokkan dalam analisis SWOT. Dikatakan sebagai analisis SWOT karena meliputi kekuatan (S: strengths), kelemahan (W: weaknesses), peluang (O: opportunities), dan ancaman (T: threats). THGA dapat dikelompokkan sebagai faktor internal/eksternal dan kekuatan pendorong/ penghambat sehingga tantangan, hambatan, gangguan, dan ancaman menempati kotak yang berbeda-beda (gambar 8).

Mempertimbangkan pada definisi THGA dan pengelompokkan pada faktor internal/ 


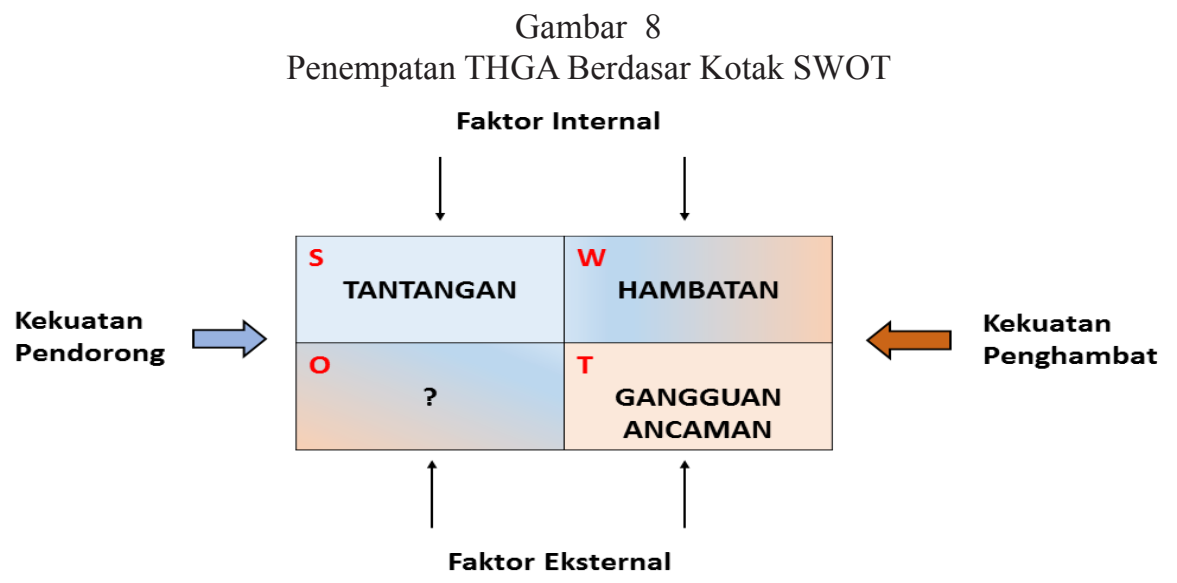

(Dikembangkan oleh Peneliti)

eksternal maupun kekuatan pendorong/ penghambat maka dalam perspektif Tannas, PI dikategorikan sebagai gangguan/ancaman (potensial) karena merupakan faktor eksternal dan kekuatan penghambat yang dapat memperburuk aspek alamiah dan aspek sosial. Permasalahannya, di antara THGA tidak ada yang menempati kotak $\mathrm{O}$ atau peluang (opportunities), sehingga tidak bisa dilanjutkan dengan penyusunan strategi berdasarkan matriks faktor THGA.

Ketiadaan kotak O, perlu disadari bahwa paradigma yang digunakan oleh Lemhannas (2015) didominasi oleh pendekatan kemiliteran sehingga mengartikan segala bentuk THGA diperlakukan sebagai sesuatu yang aktual, padahal hal-hal yang membahayakan eksistensi bangsa tidak jarang berbentuk potensial; PI adalah salah satu contohnya. PI merupakan gangguan/ancaman yang bersifat potensial sehingga untuk memeranginya dilakukan dengan cara yang sama sekali berbeda dengan pendekatan kemiliteran.

Dua konsep utama dalam menghadapi gangguan/ancaman PI adalah mitigasi dan adaptasi. Mitigasi adalah upaya mengatasi penyebab sedangkan adaptasi adalah penyesuaian terhadap iklim. Mitigasi dilakukan untuk mengurangi risiko dan dampak pemanasan global dan perubahan iklim di masa depan. Beberapa contoh upaya mitigasi adalah program diversifikasi sumber energi (Perpres No. 5/2006), Penurunan emisi nasional sebesar $26 \%$ dengan upaya sendiri dan $41 \%$ jika mendapat bantuan luar negeri hingga 2020 (Perpres No. 61/2011), dan Inventori emisi gas rumah kaca nasional (Perpres No. 71/2011). Selanjutnya, terdapat 3 strategi dalam melakukan adaptasi, yaitu adaptasi fisik, adaptasi sosial-ekonomi, dan adaptasi sumber daya manusia (Rahmasari, 2011). Contoh kegiatan dalam adaptasi fisik dapat dilakukan dengan pembuatan tembok penahan gelombang laut; adaptasi sosial-ekonomi dilakukan dengan beralih mata pencaharian; dan adaptasi sumber daya manusia seperti manajemen pasca panen.

\section{Keamanan Manusia Dan Ketahanan Nasional}

Pemahaman tentang bentuk-bentuk ancaman bagi eksistensi sebuah negara telah mengalami perubahan. Ancaman negara tidak hanya berupa ancaman militer (ancaman tradisional), namun ancaman dapat berasal dari berbagai sumber seperti degradasi 
lingkungan, terorisme, illegal logging, dan human trafficking (ancaman non tradisional). Pada tahun 1994, United Nation Development Programme (UNDP, 1994) mengusung istilah human security (keamanan manusia) sebagai pengganti terminologi national security (keamanan nasional). Berbagai bentuk ancaman dikategorikan sebagai ancaman yang harus diperangi apabila mengancam keamanan manusia/individu. Dengan demikian, ancaman non tradisional (dalam hal ini, PI) sudah seharusnya menjadi agenda keamanan, isu pertahanan dan kepentingan nasional (Schoch, 2011).

Sampai saat ini, Indonesia belum memiliki UU keamanan nasional sehingga sering ditemukan pemahaman yang saling terpisah antara pertahanan dengan keamanan (Hankam). Permasalahan ini bermula dari TAP MPR RI No. VI/2000 (Pemisahan TNI dan Polri) dan TAP MPR RI No. VII/2000 (Peran TNI dan Peran Polri). Tugas pertahanan dibebankan kepada TNI dan tugas keamanan kepada Polri. Padahal seharusnya dimensi keamanan nasional sudah mencakup pertahanan (TNI) dan keamanan (Polri); keamanan dalam makna yang lebih luas menempatkan TNI maupun Polri sejajar dengan aktor di bidang politik, ekonomi, dan sosial bahkan di bidang lingkungan hidup (Perwita, 2008).

Fungsi Hankam dilaksanakan oleh TNI dan Polri sebagai kekuatan utama, serta didukung oleh rakyat (Ps 30 ayat 2 UUD'45). Pasal ini mengisyaratkan bahwa antara fungsi pertahanan-keamanan tidak dapat dipisahkan. Selain itu, untuk menggali konsepsi keamanan nasional, salah satunya dapat dilakukan dengan memahami secara lebih mendalam tentangkonsepsi Tannas. Tannas merupakan konsepsi atau landasan utama dalam menjamin keberlangsungan kehidupan bangsa yang diwujudkan melalui kondisi kehidupan warganya yang tangguh.

Dalam konteks ke-Indonesia-an, pada dasarnya Tannas telah mencakup keamanan negara dan kesejahteraan bagi seluruh warga negara yang berlandaskan Astagatra (Trigatra dan Pancagatra).Trigatra(tiga aspek alamiah) meliputi letak geografis, sumber kekayaan alam, dan potensi/kemampuan penduduk. Pancagatra (lima aspek sosial) terdiri dari ideologi, politik, ekonomi, sosial-budaya, dan pertahanan/keamanan. Ketahanan nasional lebih mengedepankan kepada terwujudnya ketahanan individu/manusia dengan alasan bahwa ketahanan dalam skala nasional hanya dapat terwujud apabila seluruh individu telah memiliki ketahanan yang tangguh. Pertanyaannya sekarang, bagaimana keterkaitan antara keamanan manusia dengan Tannas.

Konsepsi keamanan dalam pendekatan non tradisional, lebih menekankan kepada pelaku bukan negara (non state actors). Konsepsi keamanan lebih difokuskan kepada upaya untuk menjamin keamanan warga atau human security. Human security seringkali diposisikan sebagai comprehensive security (keamanan yang menyeluruh), yaitu pendekatan keamanan yang tidak hanya memandang aspek keamanan dalam perspektif kemiliteran. Keamanan dianggap hadir manakala masyarakat telah mendapatkan kebebasan dari berkeinginan (freedom from want) dan dari rasa takut(freedom from fear). Keamanan tercipta tidak dengan cara mengurangi kebebasan individu/masyarakat (Collins, 2005).

Konsep Tannas dapat disejajarkan dengan paradigma keamanan komprehensif. Tannas mirip dengan keamanan komprehensif karena memandang keamanan 
dari berbagai pendekatan (multidimensi). Keamanan tidak hanya dilihat dari sisi militer, tetapi mencakup spektrum yang jauh lebih luas, termasuk aspek ekonomi, politik, dan sosial (Dewi Fortuna Anwar dalam Susetyo, 2008). Meskipun pada prakteknya, paradigma komprehensif dalam Tannas, pendekatan kemiliteran tetap masih menonjol. KonsepTannas di Indonesia, pada awal kemunculannya pada tahun 1960an dimaksudkan sebagai upaya militer Indonesia dalam menghadapi berbagai konflik di bidang politik dan keamanan dalam negeri (Mutthiah Alagappa dalam Acharya, 2001), termasuk sebagai upaya untuk menangkal komunisme.

Pendekatan keamanan manusia dapatdigunakan sebagai pilihan karena telah mampu mengakomodasi keamanan dalam berbagai sektor, yaitu sektor militer dengan sektor lainnya, seperti ekonomi, pangan, dan energi, bahkan sektor lingkungan. Norwegia merupakan contoh negara yang dalam mengembangkan keamanan nasionalnya menggunakan pendekatan human security. Negara tersebut terbukti memiliki keamanan nasional yang relatif solid, bahkan memiliki Human Development Index (HDI) pada tahun 2016 menempati ranking 1 (satu) dengan skor sebesar 0,949 (UNDP, 2016).

\section{SIMPULAN}

Dari pembahasan tentang penyebab terjadinya konflik, indikasi terjadinya perubahan iklim, konsep-konsep tentang keamanan nasional, ketahanan nasional, keamanan komprehensif, dan keamanan manusia; digabungkan dengan komparasi kebijakan keamanan dari beberapa negara dalam menyikapi berbagai risiko/dampak PI, dapat disimpulkan sebagai berikut.
Pertama, PI tidak berkorelasi secara langsung terhadap terjadinya konflik/ perang, meskipun terdapat keterkaitan antara terjadinya E1-Nino dengan peningkatan konflik. PI berpengaruh terhadap kemiskinan, ketidakstabilan politik, dan kemerosotan ekonomi. Dalam era PI, interaksi antara ketersediaan air dan kelangkaan pangan, termasuk salah urus SDA merupakan kondisi yang berkontribusi terhadap ketidakamanan. Namun, jika hanya fokus pada faktor eksternal seperti kekeringan sebagai penyebab terjadinya pemberontakan adalah kontraproduktif. Hanya akan mengalihkan perhatian dari akar permasalahan yang mendasar yaitu masalah politik maupun ekonomi dan meniadakan tanggung jawab dari pemerintahan.

Kedua, PI secara faktual telah terjadi dan mengancam keberlangsungan kehidupan manusia dan lingkungan. PI turut berkontribusi terhadap peningkatan kejadian bencana hidrometeorologi (banjir, kekeringan, tanah longsor, puting beliung, hingga gelombang pasang) yang merupakan 98,5\% total bencana di Indonesia. Bencana hidrometeorologi ini memberikan dampak yang sangat besar terutama pada sektor ekonomi dan lingkungan, baik dampak langsung maupun dampak tidak langsung sehingga dapat menurunkan tingkat Tannas.

Ketiga, dalam perspektif ketahanan nasional maka isu PI merupakan gangguan dan atau ancaman (potensial), dimana keduanya merupakan faktor eksternal dan kekuatan penghambat. Dikategorikan sebagai gangguan karena berpotensi menghambat yang dapat menyebabkan negara mudah jatuh/dikalahkan. Selain itu, dapat menjadi ancaman yang dapat menyebabkan negara menjadi kolaps secara permanen. 
Keempat, Indonesia belum memiliki UU keamanan nasional namun konsep Tannas dapat digunakan untuk mewakili konsep keamanan dalam dimensi yang lebih luas karena telah mampu menjamin kehidupan warganya dari berbagai bentuk THGA. Dengan kata lain, konsep Tannas dapat disetarakan dengan konsep keamanan manusia karena keduanya berupaya menghadirkan penjaminan keamanan, keselamatan, dan kesejahteraan individu.

\section{DAFTAR PUSTAKA}

Acharya, Amitav., 2001, 'Human Security: East Versus West?'. Institute of Defenceand Strategic Studies Singapore, tersedia di https://www.rsis.edu.sg/wp-content/ uploads/rsis-pubs/WP17.pdf, diakses pada 5 Juli 2018.

Aldrian, E., Karmini, M., Budiman., 2011, Adaptasi dan Mitigasi Perubahan Iklim di Indonesia, Pusat Perubahan Iklim dan Kualitas Udara Kedeputian Bidang Klimatologi, Jakarta: BMKG,

Baker, Aryn., 2015, 'How climate change is behind the surge of migrants to Europe', Time Magazine (7 September), tersedia di http://time.com/4024210/climatechangemigrants/diakses pada 22 Juni 2018.

Barnet, J \& Adger, W., 2007, 'Climate change, human security and violent Conflict', Geographical Journal on Climate Change, Vol. 27(3), hh. 36-47.

Bergholt, D., \& Lujala, P., 2012, 'Climaterelated natural disasters, economic growth,and armed civil conflict', Journal of Peace Research, 49(1), hh. 147-162

Bernauer, T., Böhmelt, T., \& Koubi, V., 2012, 'Environmental changes and violentconflict'. Environmental Research Letters, 7(1), 015601, hh. 1-8.

Black, R., Adger, N., Arnell NW., Dercon S., Geddes A\&Thomas D., 2011, 'The effect of environmental change on human migration', Global Environmental Change, 21(1)

BMKG, 2018. 'Iklim: Perubahan Iklim', tersedia di http://www.bmkg.go.id/ iklim/? p = proyeksi-perubahan-iklim, diakses pada 22 Juni 2018

BNPB., 2018. Tren Kejadian Bencana 10 Tahun terahir (2008-2017), tersedia di http://bnpb.cloud/dibi/laporan4, diakses pada 26 September 2018

BPPI, 2015, Buku Putih Pertahanan Indonesia (BPPI), Jakarta :Kementerian Pertahanan RI,

Brochmann, M., \& Gleditsch, N. P., 2012, 'Shared rivers and conflict - A reconsideration', Political Geography, 31(8), hh. 519-527.

Buhaug, H., 2010, 'Climate not to blame for African civil wars', $P N A S, 107$, hh. 1647716482.

CNA Military Advisory Board (CNAMAB), 2007, 'National Security and the Accelerating Risks of Climate Change', tersedia di https://www.cna.org/mab/reports, diakses pada 2 Juli 2018.

Collins, Alan., 2005, Security and Southeast Asia: Domestic, Regional, and Global Issues, New Delhi.:Viva Books Private Limited,

Dabelko, G. D., 2008, 'An uncommon peace: environment, development and the global security agenda', Environment, Vol. 50, No. 3, hh. 32-45. 
De Châtel, Francesca., 2014,'The role of drought and climate change in the Syrian uprising: Untangling the triggers of the revolution', Middle Eastern Studies, 50(4), hh. 521-535.

Dellmuth, L M; Gustafsson M T; Bremberg N., Mobjork M \& Maria, T G, 2017, 'Intergovernmental organizations and climate security: advancing the research agenda', Wiley Interdisciplinary Reviews: Climate Change, 9, 1.

Dinshaw, Fram., 2015, 'This is what a climate refugee looks like'. National Observer (4 September), tersedia di http://www. nationalobserver.com/2015/09/04/news/ what-climate-refugee-looks, diakses pada 22 Juni 2018.

Durham, W., 1979, Scarcity and survival in Central America: The ecological origins of the Soccer War. Stanford: Stanford University Press.

DWP, 2016, 'Defence White Paper (DWP)', tersedia di http://www.defence.gov.au/ whitepaper/Docs/2016-Defence-WhitePaper.pdf, diakses pada 15 Juni 2018.

Fearon, James D\&Laitin, David D., 2003, 'Additional Tables for Ethnicity, Insurgency, and Civil War', tersedia di http://www.stanford.edu/group/ethnic/ diakses pada 22 Juni 2018.

Fröhlich, Christiane., 2016, 'Climate migrants as protestors? Dispelling misconceptions about global environmental change in pre-revolutionary Syria', Contemporary Levant, 1(1), hh. 38-50. Doi: $10.1080 / 20581831.2016 .1149355$

Gleditsch, N. P., 2012, 'Whither the weather? Climate change and conflict', Journal of Peace Research, 49(1), hh. 4-9.
Hague, Rod \& Harrop, Martin., 2013, Comparative Goverment and Politics: An Introduction, London: Palgrave Macmillan, hh. 364-366.

Homer, Dixon, T. F., 1999, Environment, scarcity, and violence. Princeton: Princeton University Press

Hsiang, S. Meng \& Cane., 2011, 'Civil conflicts are associated with the global climate', Nature, 476, hh. 438-440.

Human Security Centre (HSC)., 2005, 'Human Security Report 2005: War and Peace in the 21st Century', tersedia di http://www. humansecurityreport.info/, diakses pada 30 Juni 2018.

IPCC., 2001, 'Impacts, adaptation and vulnerability', In third assessment report, Climate change 2001, Geneva/Cambridge, Switzerland: Intergovernmental Panel on Climate Change, Cambridge University Press.

IPCC., 2007, 'Impacts, adaptation and vulnerability', In fourth assessment report, Climate change 2007, Geneva/Cambridge, Switzerland: Intergovernmental Panel on Climate Change, Cambridge University Press.

IPCC., 2014, 'Climate change 2014: Impacts, adaptation, and vulnerability', IPCC working group II contribution to AR5, Geneva, Switzerland: IPCC. in press tersedia di www.ipcc-wg2.gov/AR5/, diakses pada 17 Juni 2018.

Karl, TL., 1997, The Paradox of Plenty: Oil Booms and Petro-States, Berkeley, Los Angeles and London: California University Press.

Kawser, M A and Samad, A., 2016, "Political history of Farakka Barrage and its effects 
on environment in Bangladesh". Bandung, Journal of Global South (2016) 3:16 DOI 10.1186/s40728-015-0027-5

Khalid, Iram. Bangladesh Water Concern. $A$ Research Journal of South Asian Studies Vol. 25, No. 1, January-June 2010, pp.73-87

Klare, MT., 2001, Resource Wars: The New Landscape of Global Conflict, New York: Henry Holt.

Klingman, David., 1980, 'Temporal and spatial diffusion in the comparative analysis of social change', American political science review, Vol. 74 No. 1, hh.123-137

Koubi, V., Bernauer, T., Kalbhenn, A., \& Spilker, G., 2012, 'Climate variability, economic growth, and civil conflict', Journal of Peace Research, 49(1), hh. $113-127$

Lemhannas, 2015, Sistem Dinamika Pengukuran Ketahanan Nasional dan Simulasi Kebijakan Publik, Jakarta.: Lemhannas RI,

Miguel, E., Satyanath, S \& Sergenti, E., 2004, 'Economic Shocks and Civil Conflict: An Instrumental Variables Approach', Journal of Political Economy, Vol. 112, No. 4

National Intelligence Council (NIC)., 2012, 'Global Trends 2030: Alternative Worlds', Washington, DC: National Intelligence Council, h. 30

Olufemi, F. J \& Samson, A. O., 2012, 'Climate Change, Environment and Conflicts in Nigeria', British Journal of Arts and Social Sciences, ISSN: 20469578, Vol.6 No.1

Perwita, Banyu., 2008, 'Problematika Hubungan TNI dan Polri dalam Menangani Terorisme dan Kejahatan Lintas Batas', Jurnal Ilmiah Hubungan Internasional, Vol. 4, No. 1
QDR., 2010, 'Quadrennial Defence Review (QDR)', US Department of Defence, tersedia di http://www.defense.gov/ Portals/1/features/defenseReviews/QDR/ QDR_as_of_29JAN10_1600.pdf, diakses pada 20 Juni 2018.

QDR., 2014, 'Quadrennial Defence Review (QDR)', US Department of Defence, tersedia di http://www.defense.gov/ Portals/l/features/defenseReviews/ QDR/2014_Quadrennial_Defense_ Review.pdf, diakses pada 15 Mei 2018.

Rahmasari, L., 2011, 'Strategi Adaptasi Perubahan Iklim Bagi Masyarakat Pesisir'. Jurnal Sains dan Teknologi Maritim X(1), hh. 1-11

Schoch, C., 2011, 'Rethingking climate change as a security threat', International Institute for Environment and Development (IIED): October, tersedia di http://pubs.iied.org/ $p d f s / 171011$ IIED.pdf? , diakses pada 10 Juni 2018.

Selby, Jan., Dahi Omar S., Fröhlich, C\&Hulme M., 2017, 'Climate change and the Syrian civil war revisited', Political Geography (60), hh. 232-244

Soekanto, S \& Mamuji, S., 2001, Penelitian Hukum Normatif(Suatu Tinjauan Singkat), Jakarta: Rajawali Pers

Soemitro, R H., 1988, Metodologi Penelitian Hukum dan Jurimetri, Jakarta: Ghalia Indonesia.

Stern, Nicholas., 2008, 'The Economics of Climate Change'. American Economic Review, Vol. 98 (2), hh. 1-37. DOI: 10.1257/aer.98.2.1, tersedia di http:// pubs.aeaweb.org/doi/pdfplus/10.1257/ aer.98.2.1, diakses pada 20 Juni 2018.

Suradinata, Ermaya., 2005, 'Hukum Dasar Geopolitik dan Geostrategi Dalam 
Kerangka Keutuhan NKRI', Jakarta: Suara Bebas.

Susetyo, Heru., 2008, 'Menuju Paradigma Keamanan Komprehensif Berperspektif Keamanan Manusia dalam Kebijakan Keamanan Nasional Indonesia', Lex Jurnalica, Vol. 6 No.1, Desember.

Swain, A.,1996, 'Environmental migration and conflict dynamics: focus on developing regions'. Third World Quarterly, 17(5), 959-973.

Trenberth, Kevin \& National Center for Atmospheric Research (NCAR) Staff (Eds), Last modified 02 Feb 2016, 'The Climate Data Guide: Nino SST Indices (Nino 1+2, 3, 3.4, 4; ONI and TNI)', tersedia di https://climatedataguide.ucar. edu/climate-data/nino-sst-indices-nino12-3-34-4-oni-and-tni, diakses pada 20 Juni 2018.

UCDP/PRIO., 2018, 'Rate of battle deaths in state-based conflicts by type of conflictsince 1946', Uppsala Conflict Data Program (UCDP) \& Peace Research Institute Oslo (PRIO), tersedia di $w w w$. prio.org/Data/Armed-Conflict, diakses pada 21 Juni 2018.

UNDP., 1994, 'Human Development Report 1994', tersedia di http://hdr.undp.org/ sites/default/files/reports/255/hdr_1994_ en_complete_nostats.pdf, diakses pada 20 Juni 2018.

UNDP., 2016, 'Human Development Report 2016', tersedia di http://hdr.undp.org/ en/2016-report, diakses pada 20 Juni 2018.

Urdal, Henrik., 2005, 'People vs. Malthus: Population pressure, environmental degradation, and armed conflict revisited', Journal of Peace Research, 42(4), hh. 417-434.

USAID., 2009. Conflict Assessment Framework, tersedia di http://pdf.usaid. gov/pdf_docs/pnady739.pdf, diakses pada 11 Juni 2018

Werrell, C.E., Femia, F\&Sternberg, T., 2015, 'Did we see it coming? State fragility, climate vulnerability, and the uprisings in Syria and Egypt',SAIS Review, 35(1), hh. 29-46.

\section{Peraturan Perundangan}

Undang Undang Nomor 2 Tahun 2002 Tentang Polri

Undang Undang Nomor 3 Tahun 2002 Tentang Pertahanan Negara

Undang Undang Nomor 34 Tahun 2004 Tentang TNI 